\title{
Clarification and Changes in Permian Stratigraphic Nomenclature in Kansas
}

\author{
Robert S. Sawin ${ }^{1}$, Evan K. Franseen ${ }^{1}$, Ronald R. West ${ }^{2}$, \\ Greg A. Ludvigson ${ }^{1}$, and W. Lynn Watney ${ }^{1}$
}

\author{
${ }^{1}$ Kansas Geological Survey, 1930 Constant Avenue, Lawrence, Kansas 66047 \\ ${ }^{2}$ Emeritus Professor, Kansas State University, Manhattan, Kansas 66506 \\ ${ }^{1,2}$ Member, Stratigraphic Nomenclature Committee, Kansas Geological Survey
}

\begin{abstract}
This paper outlines Permian nomenclature changes to Zeller (1968) that have been adopted by the Kansas Geological Survey. The Permian System/Period, Cisuralian Series/Epoch, and Asselian Stage/Age are established at the base of the Bennett Shale Member of the Red Eagle Limestone. Series/epoch names Wolfcampian, Leonardian, and Guadalupian are retained and usage of Gearyan, Cimarronian, and Custerian is abandoned. The repositioned Carboniferous-Permian boundary divides the Council Grove Group into Carboniferous (Upper Pennsylvanian Series/Epoch; Virgilian Stage/Age) and Permian (Wolfcampian Series/ Epoch) segments.
\end{abstract}

\section{Introduction}

Zeller (1968) is the current accepted stratigraphic guide and chart for Kansas. This paper outlines and discusses Permian nomenclature changes to Zeller (1968) that are now formally adopted by the Kansas Geological Survey (KGS) (fig. 1).
These revisions are based on the principles that nomenclature changes will follow the North American Code of Stratigraphic Nomenclature (2005), and changes will conform to international stratigraphic nomenclature standards as they apply to Kansas.

\section{Background and Justification}

Zeller (1968) adopted the two-fold classification published by O'Connor (1963) that divided the Permian into Lower and Upper series. The Lower Permian Series was subdivided into two stages, the Gearyan (oldest) and Cimarronian (youngest); the Upper Permian Series had only one stage, the Custerian. O’Connor (1963) named the Gearyan and Cimarronian stages; Zeller (1968) the Custerian Stage, citing work by Fay (1965). This two-fold classification replaced the three-fold series names Lower, Middle, and Upper Permian, and the stage names Wolfcampian, Leonardian, Guadalupian, and Ochoan of Jewett (1959).

Baars (1990) abandoned the terms Lower Permian Series and Upper Permian Series in Kansas because they "are too general to be of value and create cumbersome classifications” (p. 689) and suggested they only be used informally. He also abandoned the locally derived stage names Gearyan, Cimarronian, and Custerian because they had not been widely accepted, and reinstated Wolfcampian, Leonardian, and Guadalupian as series names. Rock units previously assigned to the Gearyan, Cimarronian, and Custerian were reassigned to the Wolfcampian, Leonardian, and Guadalupian, respectively. Rocks of Ochoan age are not thought to occur in Kansas (Rascoe and Baars, 1972; Baars, 1990); however, Jewett (1959) and Dunbar et al. (1960) included the Day Creek Dolomite and the Big Basin Formation ("Taloga") in the Ochoan, and Mudge (1967) and Menning et al. (2006) raised the possibility as well.

\section{Series/Epochs}

The International Commission on Stratigraphy (ICS) divides the Permian into three series/epochs-in ascending order: Cisuralian, Guadalupian, and Lopingian—and Global Stratotype Sections and Points (GSSP) are established at the base of each (Wardlaw et al., 2004).

The base of the Cisuralian Series/Epoch is established in Kansas at the base of the Bennett Shale Member of the Red Eagle Limestone (Boardman et al., 1998; Sawin et al., 2006).

The GSSP for the base of the Guadalupian (top of the Cisuralian) is located in the southern Guadalupe Mountains of Texas in the Cutoff Formation and is marked by the first occurrence of the conodont Jinogondolella nankingensis (Wardlaw et al., 2004; Glenister et al., 1999). The Wolfcampian and Leonardian regional series in North America are approximately equal to the Cisuralian (the traditional Leonard top is slightly below the Cisuralian top [Menning et al., 2006, p. 353, fig. 4]). The conodont Jinogondolella nankingensis has not been reported in Kansas, and correlations of Permian rocks from Texas to Kansas remain uncertain. The generally accepted boundaries for the base of the Leonardian and Guadalupian (North American terminology) in Kansas have, for the most part, been arbitrary, with little or no basis or explanation for their position. Because the correlative equivalents are not firmly established in Kansas, no changes to Zeller (1968) are made at this time.

The GSSP for the base of the Lopingian is located in South China, but, as mentioned above, most work suggests the uppermost Permian rocks in Kansas are probably no younger than Guadalupian. 


\section{Stage/Age}

The ICS divides the Cisuralian Series into four stages (in ascending order: Asselian, Sakmarian, Artinskian, and Kungurian), but only the base of the Asselian and the top of the Kungurian have ICS-ratified boundaries. GSSP's have been proposed for the base of the Sakmarian, Artinskian, and Kungurian (Chuvashov et al., 2002a, 2002b), but they have not been ratified.

In Kansas, the base of the Asselian Stage/Age occurs at the base of the Bennett Shale Member of the Red Eagle Limestone (Boardman et al., 1998; Sawin et al., 2006).

The position of the proposed base of the Sakmarian Stage/Age, defined by the first occurrence of the conodont Sweetognathus merrilli, is variously reported as "in” the Eiss Limestone Member of the Bader Formation (Mei et al., 2002, p. 60; Wardlaw et al., 2006), in the "upper part" of the Eiss limestone (Menning et al., 2006, p. 347), or "within” the Eiss limestone (Wardlaw, 2004; Menning et al., 2006, p. 353) in Kansas.

The position of the proposed base of the Artinskian Stage/Age, defined by the first occurrence of the conodont Sweetognathus whitei, is also variously reported as "near the base" of the Florence Limestone Member of the Barneston Formation (Wardlaw, 2004), “in” the Florence limestone (Mei et al., 2002, p. 60; Wardlaw et al., 2006), and "in the Schroyer to Florence limestones” (Menning et al., 2006, p. 348) in Kansas.

Wardlaw (2004) stated that the Kungurian Stage/Age "is not represented by good marine faunas in Kansas.” Menning et al. (2006) suggested (in their fig. 4, p. 334) that the base of the Kungurian in Kansas may be at the base of the Odell Shale, but they acknowledged that this position is questionable.

Within the Guadalupian Series, GSSP's are established for the stages (in ascending order: Roadian, Wordian, and Capitanian) (Wardlaw et al., 2004), but the placement of these boundaries, or even their occurrence, in Kansas is not known. As discussed by Norton (1939, p. 1,802), the basal contact of the Guadalupian in Kansas may or may not be conformable. Newell
(1940), in a restudy of the invertebrate fauna of the Whitehorse Formation of Oklahoma, Texas, and New Mexico, showed that these rocks were late Permian (Capitanian) in age. Skinner (1946) reported similar results based on fusulinids. Dunbar et al. (1960) assigned the Whitehorse in Kansas to the Capitanian and noted it was "virtually unfossiliferous" and that correlations were "based on physical stratigraphy” (p. 1,789). Because fossils have not been recognized in the rocks assigned to the Guadalupian in Kansas, and because the correlation of these rocks to their assumed equivalents in West Texas, Oklahoma, New Mexico, Colorado, and Wyoming are based solely on lithostratigraphy and subsurface correlations, the age of these rocks in Kansas remains enigmatic. Therefore, no changes are made to Zeller (1968) at this time.

\section{Council Grove Group and Neva Limestone Member}

In conjunction with a proposed repositioning of the Carboniferous-Permian boundary in Kansas to the base of the Neva Limestone Member of the Grenola Limestone (Baars, Ross, et al., 1994), Baars, Ritter, et al. (1994) elevated the Neva limestone to formation status, moved the base of the Council Grove Group-top of the Admire Group to the base of the Neva limestone, and moved the base of the Wolfcampian-top of the Virgilian Series/Epochs to the base of the Neva limestone. Because the Carboniferous-Permian boundary is now firmly established at the base of the Bennett Shale Member of the Red Eagle Limestone (Boardman et al., 1998; Sawin et al., 2006), the changes proposed by Baars, Ross, et al. (1994) and Baars, Ritter, et al. (1994) are no longer relevant and are therefore abandoned. The top of the Admire Group-base of the Council Grove Group remains at the base of the Foraker Limestone (Zeller, 1968), thus splitting the Council Grove Group between the Carboniferous and Permian, which, according to the North American Stratigraphic Code, is appropriate (see discussion in Sawin et al., 2006, p. 11). The top of the Virgilian (Carboniferous) Stage/Age and the base of the Wolfcampian (Permian) Series/Epoch boundaries are coincident with the Carboniferous-Permian boundary.

\section{Summary of Formally Adopted Permian Stratigraphic Nomenclature Changes}

The following clarifications and changes are adopted by the Kansas Geological Survey:

1. The coincident base of the Permian System/Period, Cisuralian Series/Epoch, and Asselian Stage/Age is established in Kansas at the base of the Bennett Shale Member of the Red Eagle Limestone (Boardman et al., 1998; Sawin et al., 2006).

2. The position of the ICS series/epoch boundaries (except for the base of the Cisuralian) cannot be determined in Kansas; therefore, the regional series/epoch names (Wolfcampian, Leonardian, and Guadalupian) are retained and the terminology of Zeller (1968) (Gearyan, Cimarronian, and Custerian) is abandoned as suggested by Baars (1990). The terms "upper" and "lower" Permian are only to be recognized as informal terms.
3. Proposed GSSP's for the ICS stage/age boundaries (except for the base of the Asselian) of the Cisuralian Series/Epoch have not been ratified, and their exact location in the Kansas section remains uncertain. Therefore, international stage/age nomenclature will not be adopted in Kansas at this time.

4. The lower and upper boundaries of the Council Grove Group remain at the base of the Foraker Limestone and the base of the Wreford Limestone, respectively (Zeller, 1968). The Carboniferous-Permian boundary located at the base of the Bennett Shale Member of the Red Eagle Limestone divides the Council Grove into Carboniferous and Permian segments.

5. The boundary between the Upper Pennsylvanian Series/Epoch (Virgilian Stage/Age) and the Wolfcampian Series/Epoch is repositioned to the base of the Bennett Shale Member of the Red Eagle Limestone (Carboniferous-Permian boundary). 


\section{Kansas Geological Survey Stratigraphic Nomenclature Committee}

This paper was completed by current members of the Kansas Geological Survey's Stratigraphic Nomenclature Committee, which was re-established in July 2005, to address stratigraphic issues and establish formally accepted stratigraphic nomenclature for Kansas. The Stratigraphic Nomenclature Committee is the official arbiter of stratigraphic nomenclature and issues in Kansas, subject to review by the State Geologist.
More information about the Committee and Kansas stratigraphic nomenclature is available at http://www.kgs.ku.edu/General/Strat/ index.html.

\section{Acknowledgments}

Steve Ruppel and Troy Rasbury provided careful, constructive reviews of the manuscript, and we are grateful for their time and expertise. Marla Adkins-Heljeson is thanked for editorial and publication assistance.

\section{References}

Baars, D. L., 1990, Permian chronostratigraphy in Kansas: Geology, v. 18, p. 687-690.

Baars, D. L., Ritter, S. M., Maples, C. G., and Ross, C. A., 1994, Redefinition of the Upper Pennsylvanian Virgilian Series in Kansas; in, Revision of Stratigraphic Nomenclature in Kansas, D. L. Baars (compiler): Kansas Geological Survey, Bulletin 230, p. 11-16.

Baars, D. L., Ross, C. A., Ritter, S. M., and Maples, C. G., 1994, Proposed repositioning of the Pennsylvanian-Permian boundary in Kansas; in, Revision of Stratigraphic Nomenclature in Kansas, D. L. Baars (compiler): Kansas Geological Survey, Bulletin 230, p. 5-9.

Boardman, D. R., II, Nestell, M. K., and Wardlaw, B. R., 1998, Uppermost Carboniferous and lowermost Permian deposition and conodont biostratigraphy of Kansas, USA; in, Permian Stratigraphy, Environments, and Resources, v. 2, Y. Jin, B. R. Wardlaw, and Y. Wang, eds.: Palaeoworld, no. 9, p. 19-32.

Chuvashov, B. I., Chernykh, V. V., Leven, E. Ya., Davydov, V. I., Bowring, S. A., Ramezani, J., Glenister, B. F., Henderson, C. M., Schiappa, T. A., Northrup, C. J., Snyder, W. S., Spinosa, C., and Wardlaw, B. R., 2002a, Proposal for the base of the Sakmarian Stage-GSSP in the Kondurovsky Section, southern Urals, Russia: Permophiles, no. 41, p. 4-13.

Chuvashov, B. I., Chernykh, V. V., Leven, E. Ya., Davydov, V. I., Bowring, S. A., Ramezani, J., Glenister, B. F., Henderson, C. M., Schiappa, T. A., Northrup, C. J., Snyder, W. S., Spinosa, C., and Wardlaw, B. R., 2002b, Progress report on the base of the Artinskian and base of the Kungurian by the Cisuralian Working Group: Permophiles, no. 41, p. 13-16.

Dunbar, C. O., Baker, A. A., Cooper, G. A., King, P. B., McKee, E. D., Miller, A. K., Moore, R. C., Newell, N. D., Romer, A. S., Sellards, E. H., Skinner, J. W., Thomas, H. D., and Wheeler, H. E., 1960, Correlation of the Permian formations of North America: Bulletin of the Geological Society of America, v. 71, no. 12, p. 1,763-1,806.

Fay, R. O., 1965, Geology of Woods County: Oklahoma Geological Survey, Bulletin 106, 189 p., 4 pl.

Glenister, B. F., Wardlaw, B. R., Lambert, L. L., Spinosa, C., Bowring, S. A., Erwin, D. H., Menning, M., and Wilde, G. L., 1999, Proposal of Guadalupian and component Roadian, Wordian, and Capitanian Stages as international standards for the Middle Permian Series: Permophiles, issue 34, p. 3-11.

Jewett, J. M., 1959, Graphic column and classification of rocks in Kansas: State Geological Survey of Kansas, chart, 1 p.

Mei, S., Henderson, C. M., and Wardlaw, B. R., 2002, Evolution and distribution of the conodonts Sweetognathus and Iranognathus and related genera during the Permian, and their implications for climate change: Palaeogeography, Palaeoclimatology, Palaeoecology, v. 180, p. 57-91.

Menning, M., Alekseev, A. S., Chuvashov, B. I., Davydov, V. I., Devuyst, F. -X., Forke, H. C., Grunt, T. A., Hance, L., Heckel, P. H., Izokh, N. G., Jin, Y. -G., Jones, P. J., Kotlyar, G. V., Kozur, H. W., Nemyrovska, T. I., Schneider, J. W., Wang, X. -D., Weddige, K., Weyer, D., and Work, D. M., 2006, Global time scale and regional stratigraphic reference scales of Central and West Europe, East Europe, Tethys, South China, and North America as used in the Devonian-Carboniferous-Permian correlation chart 2003 (DCP 2003): Palaeogeography, Palaeoclimatology, Palaeoecology, v. 240, p. 318-372.

Mudge, M. R., 1967, Paleotectonic investigations of the Permian System in the United States, Chapter F, Central midcontinent region: U.S. Geological Survey, Professional Paper 515-F, p. 93-123.

Newell, N. D., 1940, Invertebrate fauna of the late Permian Whitehorse sandstone: Bulletin of the Geological Society of America, v. 51, p. 261-336.

Norton, G. H., 1939, Permian red beds of Kansas: American Association of Petroleum Geologists, Bulletin, v. 23, no. 12, p. 1,751-1,819.

O’Connor, H. G., 1963, Changes in Kansas stratigraphic nomenclature: American Association of Petroleum Geologists, Bulletin, v. 47, no. 10 , p. $1,873-1,877$.

Rascoe, B., Jr., and Baars, D. L., 1972, Permian System; in, Geologic Atlas of the Rocky Mountain Region, W. W. Mallory, ed.: Rocky Mountain Association of Geologists, Denver, Colorado, p. 143-165.

Sawin, R. S., West, R. R., Franseen, E. K., Watney, W. L., and McCauley, J. R., 2006, Carboniferous-Permian boundary in Kansas, midcontinent, U.S.A.; in, Current Research in Earth Sciences: Kansas Geological Survey, Bulletin 252, part 2, online at http://www.kgs.ku.edu/Current/2006/sawin/index.html.

Skinner, J. W., 1946, Correlation of Permian of west Texas and southeast New Mexico: American Association of Petroleum Geologists, Bulletin, v. 30, no. 11, p. 1,857-1,874.

Wardlaw, B. R., 2004, Building an international Permian System and its correlation in the USA: Geological Society of America, Abstracts with Programs, v. 36, no. 4, p. 67.

Wardlaw, B. R., Boardman, D. R., II, and Nestell, M. K., 2006, Carboniferous-Permian stratigraphy of the midcontinent: Geological Society of America, Abstracts with Programs, v. 38, no. 2, p. 4.

Wardlaw, B. R., Davydov, V., and Gradstein, F. M., 2004, The Permian Period; in, A Geologic Time Scale 2004, F. M. Gradstein, J. G. Ogg, and A. G. Smith, eds.: Cambridge University Press, p. 249-270.

Zeller, D. E., ed., 1968, The stratigraphic succession in Kansas: Kansas Geological Survey, Bulletin 189, 81 p. 
Zeller, 1968

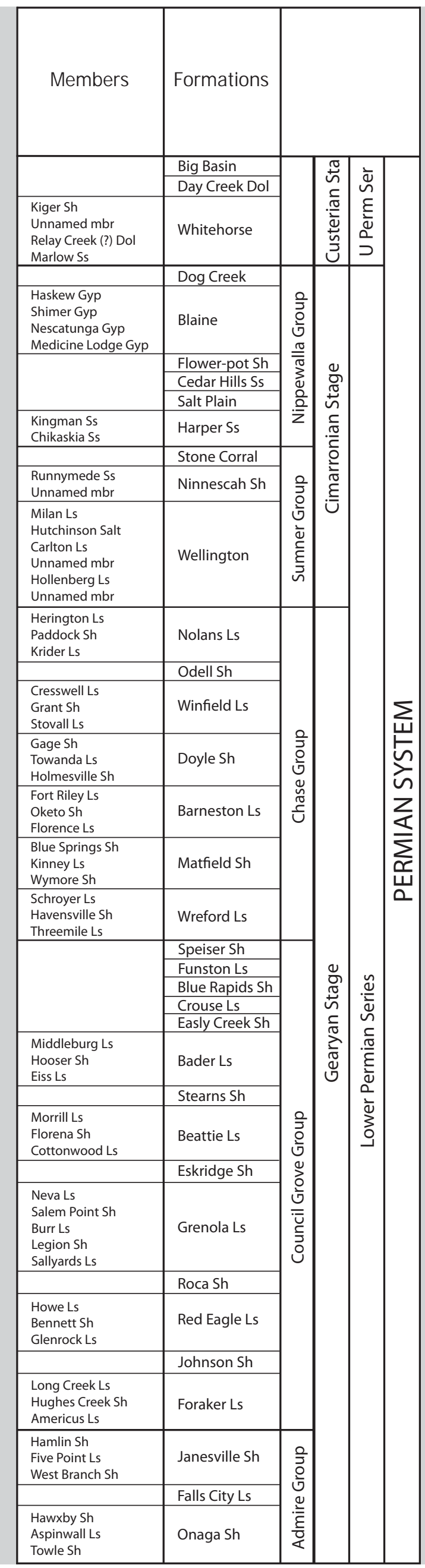

KGS Nomenclature, 2008

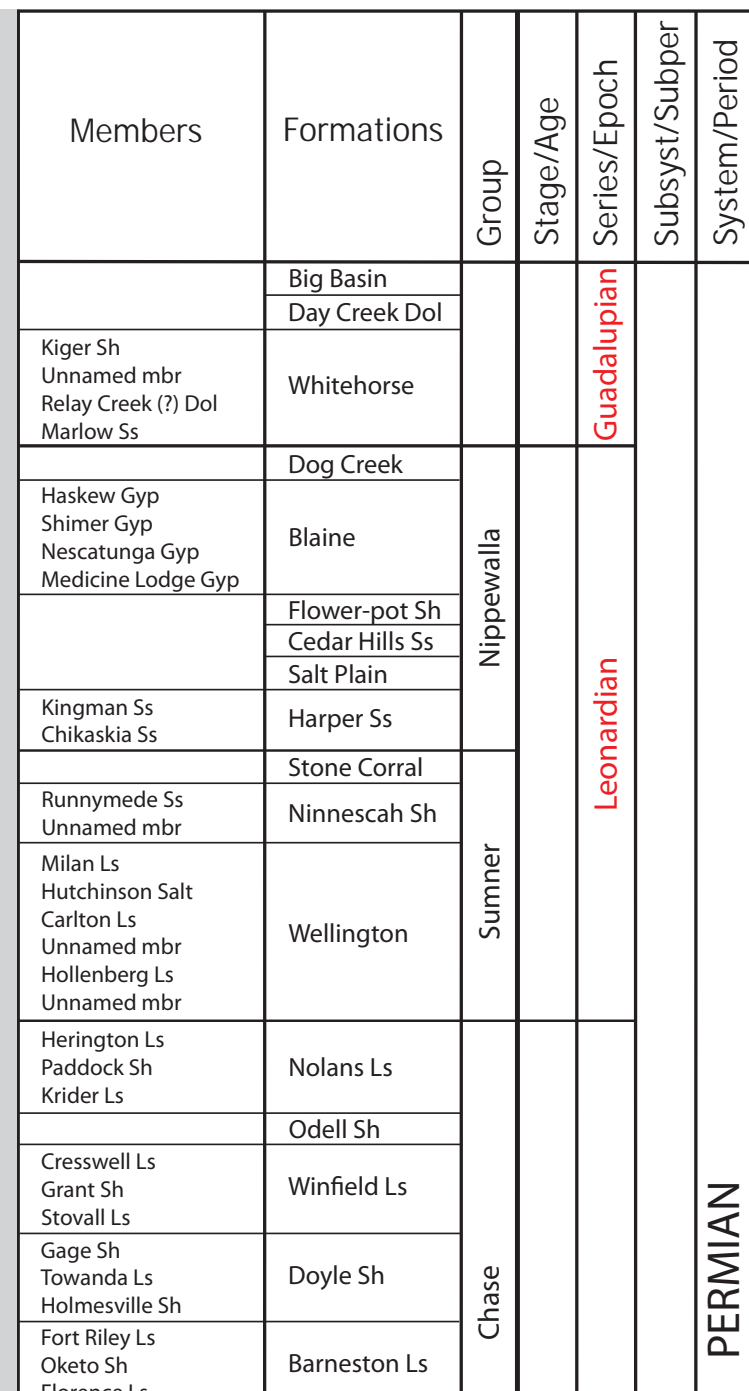

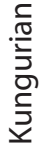

ICS Nomenclature

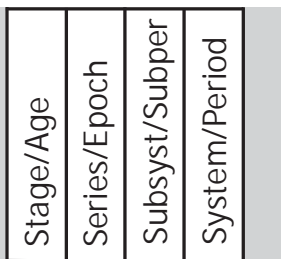

Matfield Sh

Havensville Sh

Wreford Ls

\begin{tabular}{|c|c|}
\hline $\begin{array}{l}\text { Havensville Sh } \\
\text { Threemile Ls }\end{array}$ & Wreford Ls \\
\hline & Speiser Sh \\
\hline & Funston Ls \\
\hline & Blue Rapids Sh \\
\hline & Crouse Ls \\
\hline & Easly Creek Sh \\
\hline Middl & \\
\hline
\end{tabular}

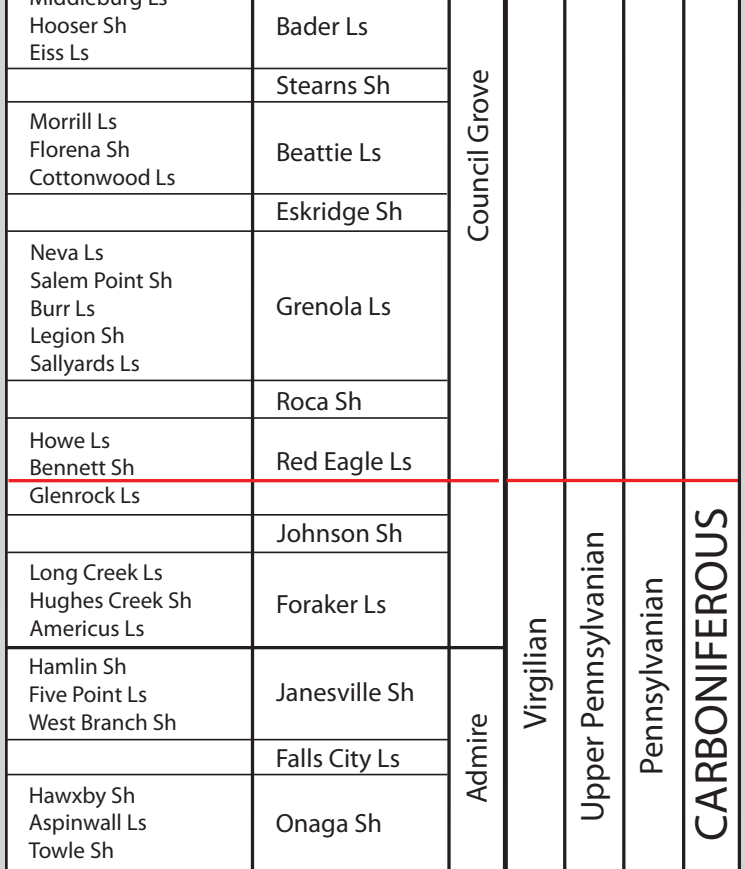

